\title{
Suhu dan Waktu Inkubasi untuk Optimasi Kandungan Eksopolisakarida dan Fitohormon Inokulan Cair Azotobacter sp. LKM6
}

\author{
Reginawanti Hindersah*), dan Rija Sudirja \\ Jurusan Ilmu Tanah, Fakultas Pertanian, Universitas Padjadjaran, \\ Jalan Raya Jatinangor Km 21 Bandung 40600 \\ Diterima 30-12-2009 Disetujui 23-09-2010
}

\begin{abstract}
Azotobacter inoculation could play an important role to enhance the effectiveness of bioremediation since bacterial exopolysachharides form a complex with heavy metal. So that metal mobility in soil and its uptake by plants increased. Azotobacter also produce phytohormone which induce roots growth and subsequently the uptake of nutrients. The objective of this research was to obtain optimal incubation temperature and time in Azotobacter sp. LKM6 liquid inoculants production in the fermentor to maximize the synthesis of exopolysachharides and phytohormones. The experiment arranged in Completely Randomized Design consisted of two incubation temperature (room temperature and $30^{\circ} \mathrm{C}$ ). At 24, 36, and 48 hours incubation, the concentration of EPS and phytohormone cytokinin and giberrelin were occurred. The experimental results were 1) the best temperature and incubation time to produce Azotobactersp. LKM6 liquid for bioremediation of heavy metal-contaminated soil was $30^{\circ} \mathrm{C}$ and 48 hours, and 2) inoculants production at $30^{\circ} \mathrm{C}$ for 48 jam produce liquid inoculants containing 2.87 $\mathrm{mg} \mathrm{L}^{-1}$ exopolysachharides, $81.0 \mathrm{mg} \mathrm{L}^{-1}$ cytokinins and $18.7 \mathrm{mg} \mathrm{L}^{-1}$ giberrelin, and $13.12 \times 10^{8} \mathrm{cell} \mathrm{ml}^{-1}$.
\end{abstract}

Keywords: azotobacter, bioremediation, cadmium, exopolysachharides, phytohormones

\section{PENDAHULUAN}

Introduksi kadmium (Cd) ke dalam tanah yang terus menerus melalui pupuk organik (Alloway, 1995), pupuk fosfat anorganik (Chien et al., 2003) atau limbah cair industri akan meningkatkan konsentrasi Cd tanah. Akibatnya adalah terjadi peningkatan akumulasi $\mathrm{Cd}$ di jaringan tanaman yang akan ditransfer ke manusia melalui jejaring makanan.

Bioremediasi tanah terkontaminasi logam menawarkan metode yang murah dan mudah. Selain itu, logam yang terakumulasi di material biologis seperti tanaman dapat diekstraksi dan didaurulang. Sejumlah tanaman akumulator logam berat dapat digunakan untuk mengakumulasi logam berat tetapi efektivitasnya sering terhambat oleh rendahnya mobilitas logam berat di tanah. Penambahan bahan organik yang berperan sebagai pengkelat logam, seperti EDTA, dapat mengintensifkan pergerakan logam berat ke permukaan akar. Salah satu bahan organik yang berperan sebagai ligan adalah eksopolisakarida (EPS) yang diproduksi beberapa bakteri (Chen et al., 1995).

\footnotetext{
*Telp: +62811221834

Email: reginawanti@yahoo com
}

Azotobacter adalah salah satu bakteri tanah yang relatif resisten terhadap Cd (Hindersah et al., 2008a) dan menghasilkan EPS (Vermani et al., 1997; Emtiazi et al., 2004; Hindersah et al., 2006). Eksopolisakarida Azotobacter dapat mengadsorpsi $\mathrm{Fe}, \mathrm{Cr}, \mathrm{Zn}$ (Emtiazi et al., 2004) dan Cd (Hindersah, 2008). Menurut Chen et al. (1995), EPS berperan sebagai ligan pengkelat logam berat Kompleks Ligan-logam berat bersifat mobil (Czajka et al., 1997) sehingga ketersediaan hayati logam meningkat. Selain itu, Azotobactermenghasilkan fitohormon yang meningkatkan pertumbuhan perakaran (Hindersah et al., 2003). Dengan demikian, inokulasi Azotobacterberpotensi meningkatkan serapan logam. Aplikasi inokulan Azotobacter di tanah dengan konsentrasi $\mathrm{Cd}$ relatif tinggi dapat meningkatkan $\mathrm{Cd}$ yang diserap tanaman akumulator seperti selada dan pakcoy (Hindersah et al., 2007) baik di tanah steril maupun tidak steril (Hindersah et al., 2008).

Untuk mengoptimalkan peran Azotobacter dalam bioremediasi logam berat terutama Cd perlu dilakukan optimasi produksi inokulan. Produksi EPS Azotobacter tergantung dari isolat atau strain (Hindersah et al., 2006; Emtiazi et al., 2004) serta sumber dan kuantitas 
karbon dan nitrogen (Vermani et al., 1997; VargasGarcia et al., 2003; Suhardiyani, 2007). Hasil penelitian dengan mikroorganisme lain menunjukkan bahwa sintesis EPS juga dipengaruhi oleh fase pertumbuhan (Petry et al., 2000; Lupi et al., 1994). Informasi mengenai pengaruh fase pertumbuhan yang berkaitan dengan lamanya proses produksi inokulan maupun suhu terhadap produksi EPS maupun fitohormon oleh Azotobacter masih sangat terbatas. Oleh karena itu penelitian ini bertujuan untuk Mendapatkan waktu dan suhu inkubasi optimal dalam produksi inokulan Azotobactersp. LKM6 untuk memaksimalkan sintesis eksopolisakarida dan fitohormon.

\section{BAHAN DAN METODE}

Bakteri yang digunakan adalah pemfiksasi $\mathrm{N}_{2}$ Azotobactersp. LKM6 yang diisolasi dari rizosfer kubis merah yang tumbuh di Andisols Lembang dan telah diinduksi untuk menghasilkan lebih banyak eksopolisakarida di media Vermani dengan N. Optimasi produksi inokulan dilakukan di dalam fermentor kaca yang tidak dapat disterilkan. Dengan demikian sterilisasi dilakukan dengan Etanol 70\%. Kapasitas maksimum fermentor adalah 2 liter dengan ukuran tabung 2,5 L yang dilengkapi dengan aerator dan pengaduk elektrik.

Produksi inokulan untuk menguji suhu dan waktu inkubasi terhadap produksi EPS dan fitohormon bakteri dilakukan di dalam fermentor dengan mengatur 1) suhu inkubasi yaitu kamar dan $30^{\circ} \mathrm{C}$ dan 2) waktu inkubasi yaitu 24, 36 dan 48 jam. Percobaan ini dilakukan pada media cair Vermani (Vermani et al., 1997) yang direkomendasikan untuk menginduksi sintesis EPS Azotobacter. Sebanyak 10\% kultur cair biakan murni Azotobacter sp. LKM6 dengan kepadatan sel $10^{9} \mathrm{cfu}$ $\mathrm{mL}^{-1}$ diinokulasikan ke dalam $1 \mathrm{~L}$ media Vermani cair di dalam fermentor steril. Fermentor untuk pengujian pada suhu kamar akan diletakkan di ruangan dengan suhu $24^{\circ} \mathrm{C}-27^{\circ} \mathrm{C}$ sedangkan untuk pengujian pada $30^{\circ} \mathrm{C}$ fermentor akan diletakkan di dalam inkubator $30^{\circ} \mathrm{C}$. Setiap fermentor diberi aerasi dari sistem aerator steril.

Pada jam ke 24, 36, dan 48 dilakukan pengambilan sampel untuk penentuan 1) konsentrasi sel dengan metode pengenceran plat (Schinner et al., 1995), 2) konsentrasi EPS dengan metode Vermani et al., (1997) yang dimodifikasi, 3) konsentrasi hormon sitokinin dan giberelin menurut Chen et al., (1986) yang dimodifikasi. Di akhir inkubasi, keasaman kultur dan kandungan diukur dengan metode potensiometri.

Optimasi dilakukan melalui suatu percobaan laboratorium yang dirancang dalam Rancangan Acak Lengkap dengan tiga ulangan. Data akan dianalisis dengan Analisis Ragam dan dilanjutkan dengan Uji Beda Nyata Terkecil pada taraf $5 \%$ menggunakan SigmaStat ver. 2.01. Dari percobaan ini akan didapatkan waktu dan suhu inkubasi optimal berdasarkan produksi EPS dengan memperhatikan konsentrasi fitohormon dan pertumbuhan bakteri.

Analisis Eksopolisakarida. Penentuan konsentrasi eksopolisakarida di dalam kultur cair diawali dengan menstrifugasi $20 \mathrm{~mL}$ kultur bakteri pada 7000 rpm (Centrifuge medium Hitachi Himac CF 7D2) pada $4^{\circ} \mathrm{C}$ selama 20 menit. Sebanyak $10 \mathrm{~mL}$ supernatan ditambah dengan $20 \mathrm{~mL}$ aseton teknis dingin dan dibiarkan semalam pada suhu $4^{\circ} \mathrm{C}$ sebelum disentrifugasi $7000 \mathrm{rpm}$ pada $4^{\circ} \mathrm{C}$ selama 20 menit. Supernatan dibuang dan eksopolisakarida (EPS) di dasar tabung dipindahkan ke kertas Whatman no. 1 yang telah ditimbang setelah pemanasan $35^{\circ} \mathrm{C}$ selama 1 jam. Kertas berisi EPS dipanaskan $35^{\circ} \mathrm{C}$ selama 1 jam dan dimasukan ke dalam desikator selama 20 menit sebelum ditimbang. Berat EPS adalah berat kertas saring dengan EPS dikurangi berat kertas saring tanpa EPS.

Analisis Fitohormon. Analisis kuantitatif fitohormon yang terdapat di dalam inokulan cair dilakukan dengan cara mengekstraksi sitokinin tersebut dengan pelarut metanol. Sebanyak $50 \mathrm{ml}$ larutan hara ditambah dengan metanol (85:15), kemudian diblender pada kecepatan 2000 rpm selama beberapa menit. Setelah itu, larutan disaring dengan kertas saring Whatman No. 40 dan diliofilisasi (Freeze-drying) sampai mencapai volume $50 \mathrm{ml}$. Sebanyak $1 \mathrm{~mL}$ ekstrak dikhromatografi kolom dengan menggunakan kolom kontinyu yang terdiri atas PVP (Polivinil Pirolidon), kolom Sepak $\mathrm{C}_{18}$ dan kolom penukar kation SCX dengan pengelusi metanol. Tinggi dan diameter kolom masingmasing $2 \mathrm{~cm}$ dan $1 \mathrm{~cm}$. Fraksi (1 ml) dikoleksi setelah 1 jam. Selanjutnya, $1 \mu$ fraksi di atas dianalisis dengan HPLC fasa terbalik dengan menggunakan kolom $\mu$ Bondapak $\mathrm{C}_{18} / 280 \mathrm{~nm}$, pelarut asetonitril $(60: 40)$ pada laju alir 1,0 mL per menit yang dioperasikan pada suhu kamar (Chen, 1987). Adanya sitokinin dan giberelin dideteksi dengan detektor UV-VIS Spektrofotometer pada panjang gelombang $254 \mathrm{~nm}$. 


\section{HASIL DAN PEMBAHASAN}

Pada penelitian ini, suhu kamar tempat produksi inokulan di gunakan berkisar antara $23-27^{\circ} \mathrm{C}$, yaitu $23-24^{\circ} \mathrm{C}$ pada malam hari dan $24-27^{\circ} \mathrm{C}$ di siang hari. Perlakuan suhu $30^{\circ} \mathrm{C}$ dilakukan di dalam inkubator dengan suhu $30 \pm 0,5^{\circ} \mathrm{C}$. Untuk kedua perlakuan, pencahayaan ruangan berasal dari lampu neon dari jam $7,00-16,00$. Selanjutnya ruangan dibiarkan tanpa cahaya. Produksi inokulan dilakukan pada fermentor beraerasi dan berpengaduk sehingga oksigenasi dan homogenitas media terjaga.

Pengambilan sampel dilakukan dengan membuka kran di dasar fermentor. Sampel sebanyak $100 \mathrm{ml}$ diambil setiap waktu pengambilan sampel. Hasil analisis terhadap parameter uji menunjukkan bahwa suhu inkubasi membedakan kualitas inokulan baik kepadatan sel Azotoacter, konsentrasi ekopolisakarida, maupun konsentrasi fitohormon sitokinin dan giberelin di dalam inokulan, baik pada waktu inkubasi 24, 36, maupun 48 jam.

Kepadatan sel. Pada Gambar 1 terlihat bahwa suhu $30^{\circ} \mathrm{C}$ lebih meningkatkan proliferasi sel Azotobacter dibandingkan suhu kamar. Pada jam ke 24 dan 36, perbedaan ini belum nyata tetapi menjadi lebih jelas pada saat pengukuran sampel yang diambil pada jam ke 48. Pada saat itu, populasi bakteri Azotobacter di dalam inokulan yang diproduksi pada

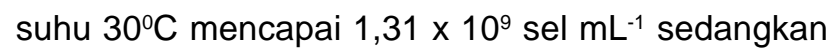

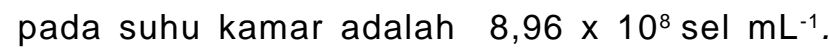
Azotobacter adalah bakteri tanah mesofil dengan suhu optimum sekitar $35^{\circ} \mathrm{C}$ (Holt et al., 1994). Dengan demikian peningkatan proliferasi pada suhu $30^{\circ} \mathrm{C}$ sesuai dengan karaktersitik fisiologinya. Produksi inokulan pada suhu $30^{\circ} \mathrm{C}$ tidak mengalami fluktuasi suhu yang

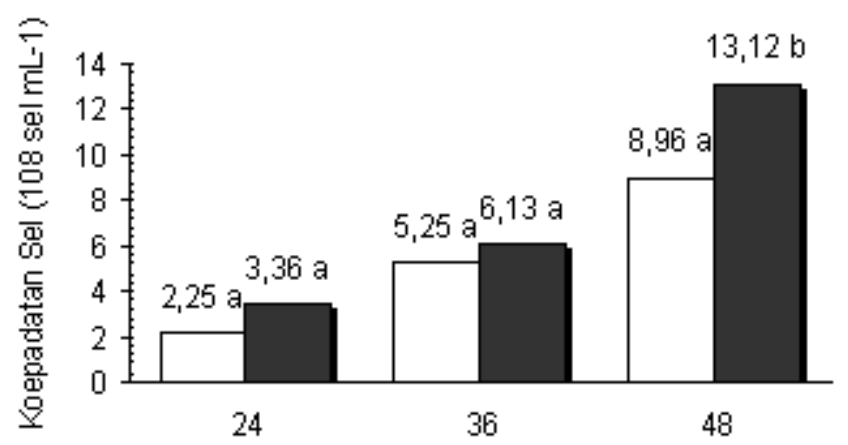

Suhu Karrar

Waktu Inkubasi (jan)

Suhu $30^{\circ} \mathrm{C}$

Gambar 1. Pengaruh waktu inkubasi terhadap kepadatan sel inokulan cair Azotobacter sp. LKM6 pada dua suhu inkubasi yang berbeda. tinggi dibandingkan dengan suhu kamar sehingga bakteri dapat melangsungkan seluruh proses fisiologis lebih baik.

Konsentrasi Eksopolisakarida (EPS). Produksi EPS oleh sejumlah bakteri tergantung dari nutrisi terutama sumber karbon, $\mathrm{pH}$, dan fase pertumbuhan (Petry et al., 2000; Emtiazi et al., 2004). Untuk Azotobacter, produksi optimum EPS dicapai pada fase logaritmik akhir (Emtiazi et al., 2004). Penelitian Hindersah (2008) memperlihatkan bahwa produksi EPS bakteri Azotobactersp. LKM6 mencapai fase akselerasi antara jam ke 40 dan 48.

Pada penelitian ini, produksi EPS tertinggi dicapai pada saat 48 jam setelah inkubasi (Gambar 2). Produksi inokulan meningkat sejak jam ke 24 sampai jam ke 48 inkubasi. Namun, peningkatan ini melambat dari jam ke 36 ke 48. Hasil ini berbeda dengan penelitian sebelumnya (Hindersah, 2008), dimana produksi EPS meningkat dengan signifikan dari jam ke 40 ke 60 . Sebaliknya, produksi EPS relatif konstan di antara jam ke 20 dan 40. Perbedaan ini dapat disebabkan karena kondisi inkubasi. Pada penelitian sebelumnya, bakteri ditumbuhkan di media yang sama tetapi di dalam tabung Erlenmeyer $100 \mathrm{~mL}$ di suhu kamar tanpa aerasi.

Produksi EPS Azotobacter lebih tinggi pada suhu $30^{\circ} \mathrm{C}$ daripada suhu kamar baik pada 24, 36 maupun 48 jam inkubasi (Gambar 2). Pada kedua perlakuan suhu, produksi EPS Azotobacter mencapai lebih dari $1 \mathrm{~g}$ per liter. Pada media yang mengandung asam hidrofenolat atau glukosa, produksi EPS Azotobacter vinelandii mencapai 0,9 dan $1,3 \mathrm{~g} \mathrm{~L}^{-1}$ setelah 48 jam inkubasi (Moreno et al., 1999). Pada penelitian kami,

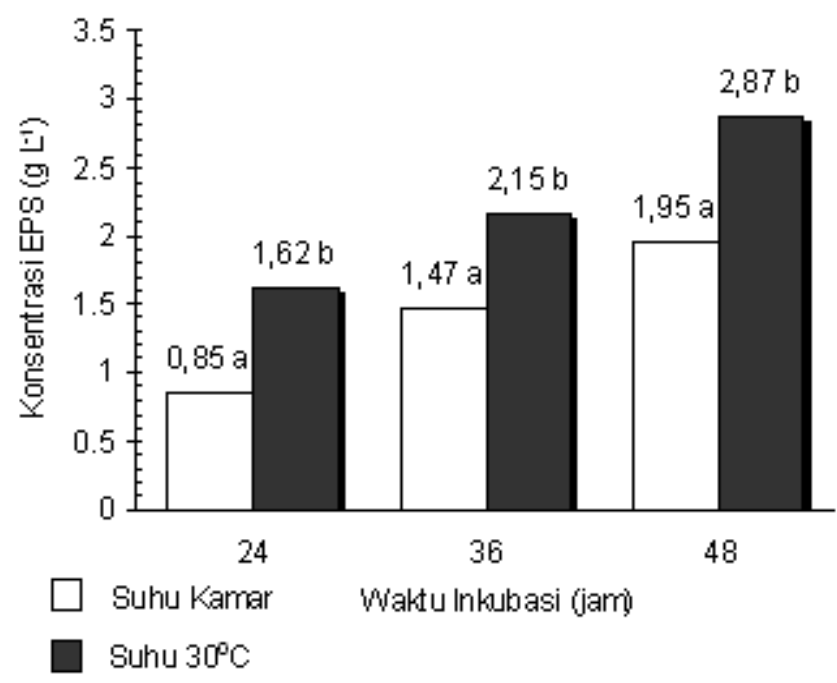

Gambar 2. Pengaruh waktu inkubasi terhadap konsentrasi EPS di dalam inokulan cair Azotobacter sp. LKM6 pada dua suhu inkubasi yang berbeda. 
digunakan sukrosa sebagai sumber karbon sesuai saran Vermani et al., (1997) yang menjelaskan pentingnya sukrosa sebagai sumber gula dalam pembentukan EPS.

Konsentrasi EPS ini jauh lebih tinggi daripada EPS yang terdapat di dalam kultur yang diinkubasi pada tabung Erlenmeyer tanpa aerasi dan pengadukan. Pada kondisi tersebut, bakteri yang sama hanya menghasilkan sekitar 600 mg eksopolisakarida per liter kultur (Hindersah, 2008). Dengan demikian jelas bahwa suhu yang kosntan, ruang fermentor yang lebih besar, serta aerasi dan pengadukan dapat lebih menjamin produksi EPS oleh Azotobacter.

Konsentrasi Fitohormon. Telah dipastikan bahwa Azotobacter memproduksi fitohormon sitokinin, giberelin, dan auksin (Taller \& Wong, 1989; Abbass \& Okon, 1993; Hindersah et al., 2000). Dijelaskan pula bahwa produksi hormon terjadi pada fase logaritmik akhir (Taller \& Wong, 1989). Pada penelitian ini, Azotobacter sp. LKM6 mensintesis sitokinin jauh lebih banyak daripada GA baik pada suhu kamar maupun $30^{\circ} \mathrm{C}$ (Gambar 3). Produksi fitohormon Azotobactersp.

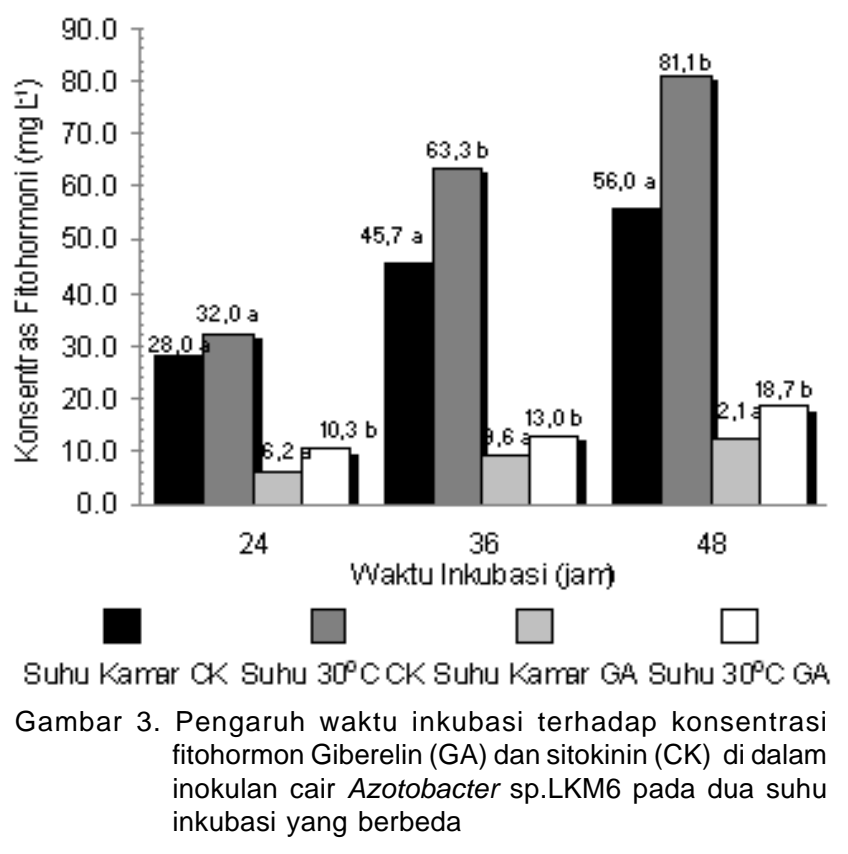

Tabel 1. Kemasaman $(\mathrm{pH})$ inokulan cair Azotobacter sp. LKM6 pada suhu dan waktu inkubasi yang berbeda

\begin{tabular}{lc}
\hline \multicolumn{1}{c}{ Kondisi inkubasi } & Kemasaman inokulan \\
\hline Suhu kamar, 24 jam & $6,3 \mathrm{~d}$ \\
Suhu kamar, 36 jam & $5,9 \mathrm{C}$ \\
Suhu kamar, 48 jam & $5,7 \mathrm{C}$ \\
$30^{\circ} \mathrm{C}, 24$ jam & $5,8 \mathrm{C}$ \\
$30^{\circ} \mathrm{C}, 36 \mathrm{jam}$ & $5,5 \mathrm{~b}$ \\
$30^{\circ} \mathrm{C}, 48 \mathrm{jam}$ & $5,1 \mathrm{a}$ \\
\hline
\end{tabular}

LKM6 selain ditentukan oleh suhu inkubasi juga ditentukan oleh waktu inkubasi dengan produksi tertinggi dicapai setelah 48 jam inkubasi, pada suhu $30^{\circ} \mathrm{C}$, yaitu sitokinin sebanyak $81,0 \mathrm{mg} \mathrm{kg}^{-1}$ dan giberelin sebanyak $18,7 \mathrm{mg} \mathrm{kg}^{-1}$.

Produksi inokulan ini dilakukan pada media Vermani yang mengandung nitrogen. Keberadaan $\mathrm{N}$ di dalam media, menurut Taller dan Wong (1989) menghambat produksi fitohormon. Namun pada penelitian ini, kedua fitohormon tetap terbentuk meskipun di akhir inkubasi terdapat 0,20\% N di dalam supernatan inokulan yang telah dibebaskan dari sel. Penelitian Hindersah et al., (2000) pada media bebas $\mathrm{N}$ hanya menghasilkan kultur cair Azotobacter chroococcum yang mengandung sitokinin dan giberelin dengan konsentrasi yang relatif kecil. Meskipun terdapat perbedaan metode ekstrasi dengan penelitian sebelumnya, keberadaan fitohormon di dalam kultur dengan $\mathrm{N}$ menandakan bahwa Azotobacter tetap memproduksi fitohormon terutama sitokinin pada kondisi inkubasi dengan $\mathrm{N}$.

Di akhir penelitian, $\mathrm{pH}$ inokulan bakteri pada suhu kamar adalah 5,7 yang lebih tinggi daripada $\mathrm{pH}$ inokulan cair pada suhu $30^{\circ} \mathrm{C}$ (Tabel 1). Di awal penelitian, $\mathrm{pH}$ inokulan cair adalah 7,0 dan telah terjadi peningkatan kemasaman sejak 24 jam inkubasi. Penurunan $\mathrm{pH}$ disebabkan oleh terbentuknya asam organik yang konsentrasinya diduga semakin meningkat dengan peningkatan waktu inkubasi. Pada suhu $30^{\circ} \mathrm{C}$ EPS yang terbentuk lebih banyak daripada suhu kamar (Gambar 2) sehingga konsentrasi asam organik diyakini meningkat mengingat salah satu komponen EPS adalah asam organik seperti asam piruvat (Omar et al., 2005) dan asam manuronat serta guluronat (Likhosherstov et al., 1991). Azotobacter adalah rizobakteri yang hidup optimal pada $\mathrm{pH}$ sekitar netral (Holt et al., 1994) meskipun Isminarni et al., (2007) dan Martyniuk \& Martyniuk (2003) telah membuktikan keberadaan Azotobacter di tanah masam. Penurunan pH inokulan sampai 5, mungkin dapat mempengaruhi daya hidup sel bakteri selama penyimpanan inokulan. Namun pendapat ini perlu dibuktikan lebih lanjut.

\section{KESIMPULAN}

Suhu dan waktu inkubasi terbaik untuk produksi inokulan cair Azotobacter sp. LKM6 untuk tujuan bioremediasi tanah tercemar logam berat kadmium adalah $30^{\circ} \mathrm{C}$ dan 48 jam. Produksi inokulan pada suhu 
$30^{\circ} \mathrm{C}$ selama 48 jam menghasikan inokulan dengan konsentrasi eksopolisakarida $2,87 \mathrm{mg} \mathrm{L}^{-1}$, sitokinin $81,0 \mathrm{mg} \mathrm{kg}^{-1}$ dan giberelin $18,7 \mathrm{mg} \mathrm{kg}^{-1}$ dengan kepadatan sel $13,12 \times 10^{8} \mathrm{sel} \mathrm{mL}^{-1}$.

\section{UCAPAN TERIMAKASIH}

Kami berterimakasih kepada DP2M Ditjen DIKTI No. 1159/H6.1/Kep/HK/2009 Atas nama Reginawanti Hendersah yang telah membiayai penelitian ini. Terimakasih pula kepada Kepala Balai Pengawasan dan Sertifikasi Benih Tanaman Pangan dan Hortikultura Jabar yang berkenan memfasilitasi sebagian peralatan.

\section{DAFTAR PUSTAKA}

Alloway, B.J. 1995. Cadmium. Di dalam: Alloway, B.J (ed). Heavy Metals in Soils. Glasgow: Blackie Academic and Professional.

Chen, C.M. 1987. Characterization of cytokinins and related compounds by HPLC. Di dalam: Linskens, H.F. and Jackson, J.F. (eds.). High performance liquid Chromatography in Plant Sciences. Berlin: Springer-Verlag.

Chen, J.H., Czajka, D. R,. Lion, L.W., Shuler, M. L. \& Ghiorse, W. C. 1995. Trace metal mobilization in soil by bacterial polymers. Environ. Health Perspect 103: 53-58.

Chien, S.H., Carmona, G., Prochnow, L.L. \& Austin, E.R. 2003. Cadmium avalability from granulated and bulk-blended phosphate-potassium fertilizers. J. Environ. Qual 32: 19111914.

Czajka, D.R., Lion, L.W., Shuler, M. L. \& Ghiorse, W. C. 1997. Evaluation of the utility of bacterial extracellular polymers for treatment of metal-contaminated soils. Polymer persistence, mobility, and the influence of lead. Water Res 31: 2827-2839.

Emtiazi, G., Ethemadifar, Z. \& Habibi, M.H. 2004. Production of extracellular polymer in Azotobacter and biosorption of metal by exopolymer. Afr. J. Biotech 3: 330-333.

Hindersah, R., Arief, D.H. \& Sumarni, Y. 2000. Kontribusi hormonal Azotobacter chroococcum pada pertumbuhan kecambah jagung dalam kultur cair. Prosiding Seminar Nasional Bioteknologi Pertanian, Yogyakarta 6-7 November 2000.

Hindersah, R., Arief, D.H., Sumarni, Y. \& Totowarsa. 2003. Produksi hormon sitokinin oleh Azotobacter. Prosiding Kongres dan Seminar Nasional Himpunan IImu Tanah Indonesia. Padang, 5-7 Juli 2003.

Hindersah, R., Arief, D. H., Soemitro, S. \& Gunarto, L. 2006. Exopolysaccharide extraction from rhizobacteria Azotobactersp. Proc. International Seminar IMTGT. Medan, 22-23 Juni 2006.

Hindersah, R., Sudirja, R. \& Setiawati, M.R. 2007. Akumulasi kadmium pada tajuk tanaman selada dan pakcoy setelah inokulasi Azotobacter sp. Ckl-5. Makalah dipresentasikan pada Seminar Kebudayaan Indonesia Malaysia. Kuala Lumpur 29-31 Mei 2007.
Hindersah, R., Arief, D. H., Soemitro, S. \& Gunarto, L. 2008. Peningkatan konsentrasi kadmium pupus selada setelah inokulasi Azotobacter dan aplikasi $\mathrm{CdCl}_{2}$ di Andisols steril dan tidak steril. Prosiding Seminar Nasional dan Dialog sumberdaya Lahan Pertanian, Bogor 18-20 November 2008.

Hindersah, R., Arief, D. H., Soemitro, S. \& Gunarto, L. 2008a. Pengaruh $\mathrm{CdCl}_{2}$ terhadap produksi eksopolisakarida Azotobacter. Jurnal Natur Indonesia 12(1): 34-37.

Hindersah, R. 2008. Transportasi kadmium dari tanah ke pupus selada oleh eksopolisakarida Azotobacter. Disertasi Pascasarjana, Bandung: Universitas Padjadjaran.

Holt, J.G., Krieg, N.R., Shaley, J.T. \& William, S.T. 1994. Bergey's Manual of Determinative Bacteriology. Baltimore: William and Wilkins.

Isminarni, F., Wedhastri, S., Widada, J. \& Purwanto, B.H. 2007. Penambatan nitrogen dan penghasilan indol asam asetat oleh isolat-isolat Azotohacter pada $\mathrm{pH}$ rendah dan alumunium tinggi. Jurnal IImu Tanah dan Lingkungan 7: 2330.

Likhosherstov, L.M., Senchenkova, S.N., Shashkov, A.S., Derevitskaya, V.A., Danilova, I.V. \& Botvinko, I.V. 1991. Structure of the major exopolysachharide produced by Azotobacter beijerinckii B-1615. Carbohydr.Res. 222: 233238.

Lupi, F. M., Fernandes, H.M.L., Tome, M.M., Sa-Correia, I. \& Novais, J.M. 1994. Influence of nitrogen source and photoperiod on exopolysaccharide synthesis by the microalga Botryococcus braunii UC 58. Enzyme and Microbial Technology 16: 546-550.

Martyniuk, S. \& Martyniuk, M. 2003. Occurance of Azotobacter spp. in some Polish soils. Polish J. Environ.Study 12: 371374.

Moreno, J., Vargas-Garcýa, C., Lopez, M.J. \& SanchezSerrano, G. 1999. Growth and exopolysaccharide production by Azotobacter vinelandii in media containing phenolic acids. Journal of Applied Microbiology 86: 439445.

Omar, M.N.A., Hanaa, A., Thabet, S.M. \& El-Beltagy, E. 2005. Exopolysachharides produced by rhizobia isolated from the rhizosphere of different plants. http://www.arc.sci.eg/ InzstsLabs (15 Oktober 2005).

Petry, S., Furlan, S., Crepeau, M.J., Cerning, J. \& Desmazeaud, M. 2000. Factors affecting exocellular polysaccharide production by Lactobacillus delbrueckii subsp. bulgaricus grown in a chemically defined medium. Appl. Environ. Microbiol 66: 3427-3431.

Suhardiyani, M. 2007. Pengaruh sumber dan konsentrasi nitrogen terhadap konsentrasi eksopolisakarida dan jumlah sel inokulan Azotobacter sp. Skripsi Fakultas Pertanian. Bandung: Universitas Padjadjaran.

Vargas-Garcia, M.C., Lopez, M.J., Elorrieta, M.A., Suarez, F \& Moreno, J. 2003. Properties of polysaccharides produced by Azotobacter vinelandii cultured on 4-hydroxybenzoic acid. J. Appl. Microbiol 94: 389-395.

Vermani, M.V., Kelkarand, S.M. \& Kamat, M.Y. 1997. Studies in polysaccharide production and growth of Azotobacter vinelandii MTCC 2459, a plant rhizosphere isolate. Lett. Appl. Microbiol 24: 379-383. 